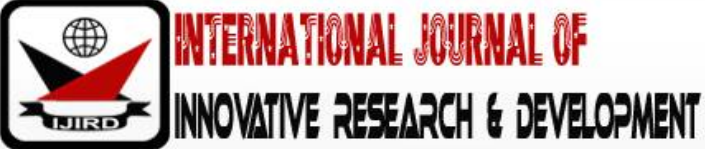

ISSN 2278 - 0211 (Online)

\section{Formulation Model of Corporate Sociall Responsibility (CSR) Oriented Strategy in Increasing the Company Performance}

\author{
Muhammad Yusuf \\ Senior Lecturer, Department of Management, Bosowa University, Indonesia \\ Firman Menne \\ Head, Department of Accounting, Bosowa University, Indonesia
}

\begin{abstract}
This research is based on the reality conditions of Corporate Social Responsibility (CSR) activities which are identical with generic CSR programs. So far, many companies have implemented CSR on the basis of external pressures, such as; regulators, environmentalists and other associations. CSR implementation is not internal awareness of the company to contribute to improve social environment, and hasno relation with main activities and company strategy, so give no benefit contribution either to company performance or competitiveness. The research focus is to develop concept of CSR implementation based on the company's internal awareness, by investigating the leader behavior in formulating corporate strategy which is oriented to corporate social responsibility (CSR) in order to increase the company's performance through the CSR implementation that is integrated to company strategy. This study will be conducted at the Makassar Industrial Area (PT KIMA). The research analysis unit is company. Respondents were sampled as many as 81 leaders of general manager level and leaders at functional manager level of the company. The analytical method used to test the hypothesis is a variance based Structural Equation Model (SEM) with the Partial least Square (PLS) program. The perspective of employees, customers, investors, communities, environment and the perspective of suppliers in the implementation of corporate social responsibility (CSR) give real contribution toward corporate performance improvement as measured by the perspectives of the balanced scorecard (BSC).
\end{abstract}

Keywords: Leader behavior, strategy formulation, CSR

\section{Introduction}

\subsection{Background}

At the end of 20th century, discourse about CSR startedto get attention from participants of Earth Summit in Rio Janeiro, Brazil in 1992 which agreed to change the development paradigm, from economic growth becomes sustainable development. Derivation from the deal, impact to business sector with the increasingpressure to companies to not only stand on single bottom line that is corporate valuethat is only reflected with level profitability, however the company responsibility should stand on triple bottom line.

Company responds to the pressure by implementing generic programs of corporate social responsibility(CSR) as the consequence and the social and environmental responsibility. Stakeholder theory says that company is not an entity that only operates for its own sake but must provide benefits to its stakeholders (Freeman, 1984). The company survival will depend on the ability of managers to create adequate wealth and satisfaction for their main stakeholders (Clarkson, 1995).

Implementation of generic CSR program so far has no connection with the main activities and corporate strategy, so it does not contribute good benefit to companies. So CSR implementation is carried out only to abort the obligations under stakeholder pressure and the regulator rules, not based on company awareness (Porter and Kramer, 2002). CSR implementation like this does not have positive impact on the performance and competitive advantage of company because these activities are not based on the company's main strategies and activities (Porter and Kramer, 2002). Placing the CSR as part of the company's strategy has been stated by Levine et al ., (2008) stating that Strategic CSR activities can increase various competitive advantages, such as brand reputation, employee awareness and enthusiasm and good relations with regulators and consumers. Graafland et al., (2003); Verissimo and Lacerda (2011); Kranz and Santalo (2010) both argue that companies that apply CSR will strategically gain product competitiveness.

This research was motivated to justify some theories that underlying this research. Some theories that underlying this research will also be justified in testing this study, among others, corporate sustainability theory,legitimacytheory, stakeholder theory, strategy leadership theory, and corporate accountability theory.

This research is expected to contribute theoretically, by giving contribution that can expand and enrich the corporate sustainability theory where competitive advantage and operational performance can become the consequences 
of the CSR-oriented business strategy implementation. It is also hoped that CSR can be part of the business vision and strategy so the corporation will enjoy reputation and the increasing business value and long-term profit growth. Besides that, by implementing CSR strategically it will improve the company's performance and obtain product competitiveness. For policy makers, this research is also expected to be useful for stakeholders and regulators as reference to evaluate the activity importance of social responsibility.

Mishra and Beacon (2010), also found positive relationship of the CSR implementation on company performance. This study measures the CSR implementation with stakeholder orientation which elaborates between internal and external aspects of the company. Indicators that are developed to measure the implementation of CSR with a stakeholder theory approach. Stakeholdertheory says that a company is not an entity that only operates for its own sake but must provide benefits to its stakeholders (Freeman, 1984). The success and survival of company will depend on the manager ability to create wealth and sufficient satisfaction to the main stakeholders (Clarkson, 1995). The company's main stakeholders are divided into six perspectives comprising: the employee perspective, consumerperspective, investor perspective, community perspective, environmental perspective and supplierperspective.From the research of Mishra and Beacon (2010), found that the increasing size of aggregate perspective to the CSR implementation is able to improve financial performance and non-financial performance of the company.

Testing the relationship between CSR implementation and company performance still needs to be done because theoretically CSR concepts always experience development in more comprehensive and integrated direction with other aspects such as leadership, behavioral and culture. On the other hand, there are still few studies that examining the CSR implementation effects on corporate financial and non-financial performance simultaneously, such as balanced scorecard, six-sigma or Malcolm Baldrige.

Furthermore, David Grayson, et al ., In the Club of Rome, (2008), gives new thinking (The New Mindset) to corporate sustainability, that the business world needs to see the interests suitability between increasing added value for shareholders, while considering social and environmental impacts . Give emphasis to how the company / organization is successful and profitable as well as able to get the three elements of 'triple bottom line' simultaneously becoming more agile and innovative, as strategic entity through integrated and systematic approach. The following diagram illustrates three added value drivers joining together and integrated with the Triple Bottom Line to encourage innovation (Figure 1):

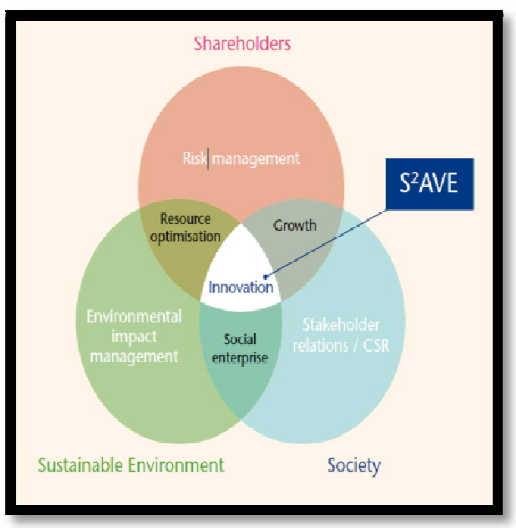

Figure 1: Balancing Demands of Investors, Environment and Society Source: David Grayson,et al., (2008).Club of Rome

This new approach to corporate sustainability considers the company obligation to provide added value not only for shareholders, but also to the communities they serve and pay attention to environmental aspects, referred to as S ${ }^{2}$ AVE (Shareholder and Social Added Value with Environment). This approach creates new complexity for manager in implementing the sustainability strategy that able to extend the value chain, and business demands to include local communities, governments, NGOs and even competitors that emphasizes on controlling the company sustainability strategy that can produce innovation throughout the organization.

Furthermore Lako (2008), explains that businessmen who want their companies live and grow lasting, they must treat CSR as essential requirement that is internalized in formulation of the vision, mission, strategy, business policy, the values of corporate culture and business actions. There are five benefits that will be achieved by companies that practice CSR as part of the company's strategy, namely: 1). Profitability and financial performance will be stronger,2).Increasing accountability and positive appreciation from the community of investors, creditors, suppliers and consumers, 3). Increased commitment, work ethic, employee efficiency and productivity, 4). The decreasing vulnerability of social upheaval and the resistance from surrounding community, 5). Increased reputation, corporate branding, goodwill (intangible assets) and long-term corporate value.

\section{Literature Review}

\subsection{Theoretical Study on Leadership Behavior}

Organizational goals can be achieved if the leader able to move and influence every member of the organization to jointly maximize their work (Northouse, 2003). This definition was sharpened by Dubrin (2001), that the leader must be able to convince every member of his organization, so jointly maximize the work to achieve organizational goals that have 
been set. Thoha (2010), states that researches of Iowa, Ohio and Michiganbecome milestone in the studies commencement on leadership related to organizational behavior. The leadership theory, among others: 1) Character Theory (Trait Theory), 2) Group Theory, relating to social psychology; 3) The situational theory and contingency model; and 4) PathGoal Theory.

The idea initiator of transformational leadership theory is strongly influenced by Burns (1978) but empirically the theory formulatedby Bass $(1985,1996)$, by distinguishing transformational leadership and transactional leadership. Transformational leaders focus to increase motivation or desire to work with subordinates (performance). The rapid development of science and technology has effect on behavior, morality and ethics. Strong tendency to think patterns and behaviors that tend to be 'practical',this tendency often results in ignoring moral and ethical values. Several studies have been conducted in relation to the ethical personality dimensions and organizational culture in relation to performance, which are used as predictive tool for the assumption success. This research was carried out by: Kujala (2001); Hitt and Collins (2007); Skerlavaj et al., 2007).

Next Huber (1991); Slater and Narver (1995) suggested the role of leadership in the implementation of organizational learning culture. Skerlavaj et al., (2006) suggested that indicators of organizational learning culture consist of a combination of three processes: (1) Information acquisition; (2) Information distribution; (3) Interpretation of information and change of mindset.

\subsection{Strategy Formulation}

Glueck and Jauch (1995) said that strategy is as a unified, broad and integrated plan that links the company strategic advantages with environmental challenges, which are designed to ensure that the company main objectives can be achieved through proper implementation by the organization. Wheelen and Hunger (2001) said that strategy formulation is a process to develop long-term plans that are effectively linked with the opportunities and challenges of the external environment and by considering the strengths and weaknesses of the company. Strategic formulations contain company mission, target specifications that can be implemented, develop strategies and policy forms. Mission is the purpose of the existence of the company itself. Strategy formulation is abstract and very decisive for decisions. Formulating strategies is determining the right way to achieve goals, including certain activities such as analysis, planning and selection of strategies that will bring up opportunities where an organizational goal will be achieved.

\subsection{Implementation of Corporate Social Responsibility(CSR)}

The implementation of CSR in company is generally influenced by several factors: the first is connected with the leader commitment; second, concerning the company scope and maturity; The third regulatory and taxation system regulated by government. This is in line with Orlitzky's opinion in Branco (2006) explaining that CSR providing internal and external benefits.

The implementation of CSR as corporate strategy is realized through the activities carried out by company towards its stakeholders including: responsibility for employees, shareholders, suppliers, involve SMEs in production activities, creating employment opportunities, and giving back benefits to the community (Griffin and Eberts , 1998) . The principles that are important in CSR implementation include: 1) Sustainability,means that program CSR must be designed to have sustainable impact; 2) CSR is long-term program, 3) CSR must have positive impact on society, both economically, socially and environmentally; 4) Funds taken for CSR are not included in company's cost structure; 5) CSR its nature is awareness, therefore it must be top-down.

\subsection{Relevant Research Results}

This research analyzes and examines the influence of corporate strategy antecedents that oriented on Corporate Social Responsibility (CSR) toward CSR implementation and strategy formulation as intervening variables. Some research results with bases of Corporate Sustainability Theory showed that to achieve CSR implementation that is integrated into corporate strategy and core competencies are influenced by antecedent factors such as: transformational leadership (Waldman et al ., 2006; Verissimo and Lacerda, 2011; and Athena Xenikou and Maria Simosi, 2006). Ethical integrity (Verissimo and Lacerda, 2011); Culture of organizational learning and the prediction of CSR values in the context of strategic decision making (Waldman et al., 2006; Triandis, 1995; House et al., 1999; Javidan et al., 2005).

This model is supported by the research results of Santalo and Kranz (2010) found that companies that are at more competitive environment, have better social level, and superior environmental performance. Theoretically, this model is supported by corporate accountability stating that the implementation of CSR is corporate fundamental obligation (KAK), so that corporations (companies) are required to be responsible for all consequences that are caused either intentionally or not toward stakeholders (Yusuf, 2013).

\section{Research Methods}

\subsection{Research Design}

This study will explain the variables position that are studied and the relationship and influence among one variable with another variables. Research that examines the relationship among research variables (explanatory research), thus this study will explain the implications of transformational leadership $\left(\mathrm{X}_{1}\right)$, ethical integrity $\left(\mathrm{X}_{2}\right)$ and Organizational Learning culture $\left(\mathrm{X}_{3}\right)$ on the formulation of company strategy that oriented to CSR $\left(\mathrm{Y}_{1}\right)$, CSR implementation $\left(\mathrm{Y}_{2}\right)$. The data that will be used is cross sectional data that will be analyzed to explain the research variables phenomenon in manufacturing companies in Makassar Industrial Area (KIMA). 


\subsection{Types and Data Collection Methods}

\subsubsection{DataType}

Data type of the research is quantitative data in the form of cross section.Cross section data is data obtained directly at the time of the observations that describe objectively the state of research objects, while the data source comes from primary data and secondary data.

\subsubsection{Data Collection Method}

- Interview, namely data collection techniques through direct interviews with respondents, namely company managers/employees. This technique is carried out to obtain technical and personal data information while supporting data that has not been covered through questionnaire.

- Questionnaires, is list of statements that are made in such way in accordance with the objectives to be achieved where respondents were asked to answer or fill in number of things relating to identity (name, age, occupation, position, last education, and tenure as a manager) and give responses to indicators of the research variables according to respondents' perceptions.

\subsection{Method and Technique of Data Analysis}

Research that aims to predict and develop theory so that the right analytical tool used is SEM equations that based on variants or partial least square (PLS).

PLS model evaluation is done by evaluating the outer model and inner model. A research concept or model cannot be tested in predictive model of relational and causal relationships if it has not passed the verification stage in the measurement model. Therefore, in the model evaluation with PLS the first step is to test the measurement model (outer mode).

\subsection{Model Interpretation and Modification}

The last stage in the SEM model is to interpret the model and modify the model for the models that do not meet the testing requirements. Hair etal., (2006) gives consideration to whether or not to modify a model by looking at the amount of residuals generated by the model. The security limit for the residual amount is $5 \%$. If the residual is greater than $2 \%$ of all covariance residuals generated by the model, then modification begins to be considered.

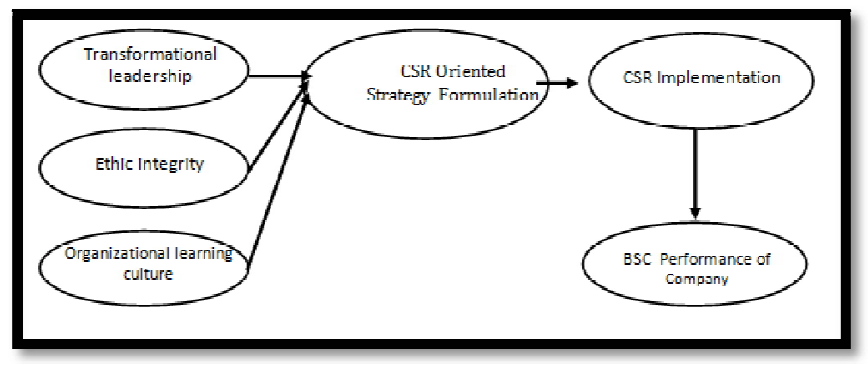

Figure 2: Research Structural Framework

\section{Empirical Research}

\subsection{Influence of CSR Oriented Strategy Formulation toward CSR Implementation.}

There is significant influence of corporate strategyformulation that is CSR oriented towards the CSR programs implementation (t- statistics9.226 greater than t- table 1.989, at alpha 0.05). CSR implementation in this study uses instrument developed by Mishar and Suar (2010). Mishra and Beacon (2010) developed CSR implementation instrument based on the stakeholder theory uses six stakeholder perspective, comprising: Employees CSR perspective, CSR consumer perspective, Investor CSR perspective, community CSR perspective, environmental CSR perspective, and suppliers CSRperspectives.

Empirically, some previous research results (Graafland et al., 2003; Verissimo and Lacerda, 2011; and Kranz and Santalo, 2010) are consistent with the study results. These three studies illustrated that companies that are implementing CSR strategy in integrated manner will enhance the company's ability to gain competitive edge. More specifically, Levine et al. (2008) stated that Strategic CSR activities can enhance variety of competitive advantages, such as brand reputation, awareness, morale and good relationships with regulators and consumers.

This hypothesis is based on the corporate sustainability theory proposed by Elkinton (1994), about the realm of thought and practice in which companies and other business organizations work to extend the life expectancy based on the aspects of the triple bottom linethat is profit, planet and place in the context of enterprise competition and survival. Lako (2008) also argued that to be able to live sustainably the company must integrate business objectives with social goals and ecological goals as a whole. Strategically the implementation of CSR programs was proposed by Porter and Kramer (2002) as philanthropic strategy. This strategy uses a partnership approach with local organizations, government, and the population can create coalitions with the wider community that are focused on improving the local economy and the environment, improving local quality of life in implementing CSR programs. 
Furthermore, it should be considered the opinion of David Grayson et al., In the Club of Rome (2008) which provides new thinking (The New Mindset) to corporate sustainability.This approach considers obligation of company toprovide added value not only for shareholders, but also to the communities they serve and pay attention to environmental aspects ( $\mathrm{S}^{2}$ AVE, Shareholder and Social Added Value with Environment). This approach creates new complexity for manager in implementing sustainability strategy that is able to extend the value chain, and business demands to include local communities, governments, NGOs and even competitors who emphasize the control of corporate sustainability strategies that can produce innovation throughout the organization.

Based on the results of the study that the indicators of profit, planet, and people as a whole for the answers of respondents each showed a fairly high means score. The profit dimension is an indicator with the highest average value of CSR-oriented company strategy formulation variables. From the study resultsit can be concluded that CSR with the dimensions of value creation in three aspects, namely: economy (Profit), environmental sustainability aspects (Planet), and social aspects (People), can be integrated with the company's strategy.

\subsection{Influence of CSR Implementation on Company Performance}

Results of hypothesis testing of CSR programs implementation toward the performance of the Balanced Scorecard (BSC), showed positive and significant correlation (t-statistics, 9.776 is greater than t-table was 1,989, at alpha 0.05). It means, if the company implements CSR programs by applying stakeholder perspective approach it will have impact on improving the financial performance and non-financial performance as measured by the perspective of balanced scorecard (BSC). The instrument used to measure financial and non-financial performance is developed by Kaplan and Norton (1996)consists of: financial perspective, consumer perspective, business process perspective and learning and growth perspective.

Empirically the study results are consistent with the results of Mishra and Suar(2010) and the research of Berman et al., (1999) which examined six dimensions of corporate social responsibility (CSR) on company performance and testing the financial (FP) and non-financial performance (NFP) of manufacturing companies. The study findings indicate that business practices that are responsible for key stakeholders can provide economic benefits for the company and benefits for all stakeholders. Research of Jose ML, et al ., ( 2008 ) showed that CSR practices are oriented towards social welfare, and are related to differentiation related to competitors, increasing the company's image that leads to economic benefits related to performance.

Theoretically this research hypothesis is based on stakeholder theory and legitimacy theory. Stakeholder theory suggests that a company is not an entity that only operates for its own sake but must provide benefits to its stakeholders (Freeman, 1984). Company survival and success will depend heavily on the manager ability to create adequate wealth and satisfaction for their main stakeholders (Clarkson, 1995). Stakeholder theory in line with the legitimacy theory (legitimacy theory) proposed by (Gray 1996) which states that organization or company will continue to exist if the community realizes that the organization operates for system that is commensurate with the community value itself. CSR-oriented strategies and implementation of CSR programs are a form of alignment to accommodate community values.

Conceptually Lawrence and Weber (2008) also stated that if corporation makes CSR as part of its business vision and strategy, then the corporation will enjoy reputation and business value increase and long-term profit growth. From the mean score of the descriptive analysis results, it can be seen the company in implementing CSR, evaluating the policy of supplier responsibility and evaluating suppliers from aspects of ecological concern well, has impact on improving company performance as measured by the perspective of balanced scorecard (BSC).

\begin{tabular}{|c|c|c|c|c|c|}
\hline Variable & $\begin{array}{c}\text { Original } \\
\text { Sample(0) }\end{array}$ & $\begin{array}{c}\text { Sample } \\
\text { Mean(M) }\end{array}$ & $\begin{array}{c}\text { Standard } \\
\text { Deviation(STDEV) }\end{array}$ & $\begin{array}{c}\text { Standard } \\
\text { Error(STERR) }\end{array}$ & $\begin{array}{c}\text { T Statistics(0 } \\
\text { / STERR) }\end{array}$ \\
\hline $\begin{array}{c}\text { Learning culture -> } \\
\text { Strategy } \\
\text { Formulation }\end{array}$ & 0.162853 & 0.185925 & 0.116386 & 0.116386 & 1.399248 \\
\hline $\begin{array}{c}\text { Strategy } \\
\text { Formulation -> CSR } \\
\text { Implementation }\end{array}$ & 0.618085 & 0.626324 & 0.066991 & 0.066991 & 9.226 .337 \\
\hline $\begin{array}{c}\text { Implementation -> } \\
\text { BSC Performance }\end{array}$ & 0.612851 & 0.621685 & 0.062685 & 0.062685 & 9.776 .644 \\
\hline $\begin{array}{c}\text { Ethics Integration - } \\
\text { > Strategy } \\
\text { Formulation }\end{array}$ & 0.336880 & 0.343671 & 0.080798 & 0.080798 & 4.169413 \\
\hline $\begin{array}{c}\text { Transformational } \\
\text { leader -> Strategy } \\
\text { Formulation }\end{array}$ & 0.295075 & 0.279786 & 0.093300 & 0.093300 & 3.162655 \\
\hline
\end{tabular}

Table 1: Testing Results Path Coefficients (Line coefficient)

In the Inner Model

Source: Data processed. 
Testing the Goodness of Fit Model measured by using the Q- square predictive relevance $\left(\mathrm{Q}^{2}\right)$ for structural models. Calculation of $\mathrm{Q}^{2}$ uses $\mathrm{R}^{2}$ data from each endogenous variable. The $\mathrm{R}^{2}$ value of each endogenous variable can be seen to in the following table:

\begin{tabular}{|c|c|}
\hline Variable & R Square \\
\hline Learning culture & - \\
\hline Strategy Formulation & 0.383996 \\
\hline CSR implementation & 0.382029 \\
\hline Ethical Integrity & - \\
\hline BSC Performance & 0.375586 \\
\hline Transformational Leader & - \\
\hline \multicolumn{2}{|c|}{ Table 2: Test Results of Determination Coefficient } \\
Source: Data processed
\end{tabular}

The total determination coefficient $\left(\mathrm{Q}^{2}\right)$ must be greater than zero (Q-square> 0 ) which indicates the model has predictive relevance; on the contrary if the value $\left(\mathrm{Q}^{2}\right)$ is smaller than zero $(\mathrm{Q}$-square $\leq 0)$ shows the model lacks predictive relevance. $\mathrm{Q}$-Square calculation $\left(\mathrm{Q}^{2}\right)$ uses the formula formulation as follows:

$\mathrm{Q}^{2}=1-\left(1-\mathrm{R}_{1}^{2}\right)\left(1-\mathrm{R}_{2}^{2}\right) \ldots\left(1-\mathrm{R}_{\mathrm{p}}^{2}\right)$.

Where $R_{1}^{2}, R_{2}^{2}$, and $R_{p}^{2}$ is the R-square of the endogenous variable in the equation model. The implementation of the Qsquare equation is as follows:

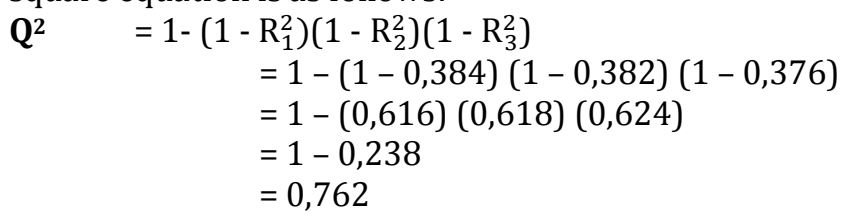

The test results of the goodness of fit inner model showed total R-square coefficient of 0,762 . The results can be described that the research model that examines the influence of Transformational leadership (X1), Ethical Integrity (X2) and Learning culture (X3) on the strategy formulation (Y1) and its effect on the Implementation of CSR (Y2) and Balanced Scorecard Performance (Y3) has prediction level that is relevant. Predictive relevance values of $(0,762)$ indicates that the diversity of data (information contained) in this study can be explained by research model of $76.2 \%$, while the remaining $23.8 \%$ is explained by other variables not surveyed in this research model. The goodness of fit

can be said to be good enough to predict the relationship between constructs, because it can explain $76.2 \%$ of the overall information.

\section{Conclusion}

Theoretical aspects of this research relate to the development of scientific management strategies at both the theoretical and empirical levels:

- This study has implications for the development of concept model of transformational leadership style and ethical integrity in its role to optimize the formulation of corporate strategies that have holistic orientation balance, both to the natural environment (planet), social environment (people) and economic orientation (profit).

- This study also provides support for the implementation of a triplebutton linetheory (TBL) in the formulation of the company's strategy to improve industry's orientation strategy towards environmental and social aspects. Beside that this theory also supports thestrategies formulation in the model of the financial and non-financial performance improvement in the concept of balanced scorecard (BSC), which mediated the implementation of corporate social responsibility (CSR).

- The findings of this study also provide theoretical implications for the application of stakeholder theory, with major stakeholder approach consisting of the perspectives of employee, customers, society, environment, investors and suppliers, and the sustainability theory in the structural model to improve the company's performance that is measured, with the findings of this study indicate the importance of implementing CSR in an integrated manner with the formulation of corporate strategy so it can optimally impact the improvement of the natural environment physically and socially. The results of this study have implications on the regulators related to the implementation of CSR in business organizations, so give more space and independence for the company in determining the approach, methods and forms of CSR program implementation that are integrated with the each company strategy.

\section{References}

i. Arendt and Brettel, 2010, Understanding the information of corporate social responsibility on corporate identity, image, and firm performance, Management Decision vol. 48.No. 10, 2010 pp. 1469-1492.

ii. Bass, BM, and Avolio, BJ, 1994, Spring, Transformational Leadership andOrganizational Culture, Quarterly Public Administration.

iii. Bass, BM and Avolio, BJ (2096). Manual for the multifactor Leadership Questionnaire, Manual and Sampler Set, 3 rd Edition, Mind Garden, Inc.

iv. Burns, JM (1978), Leadership, Harper \& Row, New York, NY. 
v. Clarkson, MBE: 1995, A Shareholder Framework for Analyzing and Evaluating Corporate Social Performance, Academy of Management Review 20 (1), 571-610.

vi. Cooper, DR, \& Schindler, PS 2006. Business Research Methods (9 ed): New York, NY: Irwin / McGraw-Hill.

vii. Dubrin.2001.Leadership: Research Findings, Practices, End Skills, Third Edition.Boston Houghton Mifflin Company.

viii. Freeman, RE 1984. Strategic Management A Stakeholder Approach. Boston: Pitman.

ix. Graalfand, J., Van De Ven, B. and Stoffele, N. (2003), 'Strategic and instruments for organizingCSR by small and large businesses in the Netherlands', Journal of Business Ethics, Vol.47,pp.45-60.

x. Ghozali, 2005. Structural Equation Modeling, Theories, Concepts and Application, 'Semarang: Diponegoro University Publisher

xi. Graa and, JJ, Ven van de, B. and Stoele, N. (2003), Strategies and instruments for your organizing CSR by small and large businesses in the Netherlands.

xii. Hair, JR., Joseph F., Rolp E. Anderson, Ropnald L. Tatham and William C. Black, 1995, 'Multivariate Data Analysis with Reading', Fourth Ed., Prentice Hall International, Inc.

xiii. Hartono, JM 2008. Methodology of Information System Research, Yogyakarta: Andi Offset

xiv. Hitt, Michael, A., Collins Jamie D., 2007. 'Business Ethics, Strategic Decision Making, and Firm Performance, Business Horizons, 50, 353-357.

xv. Hofstede, G.1991. Culture and Organization Software of the Mind, Mc Grow Hill, Book Compony. London 1991.

xvi. House, RJ, Hanges, PJ, Ruiz-Quintanilla, SA, Dorfman, PW, Javidan, M., Dickson, M., Gupta, V., \& GLOBE (1999). Cultural influences on leadership and organizations. Global leadership advances (Vol. 1, pp. 171-233). Stanford, CT: JA / Press.

xvii. Javidan, Mansour., K. Stahl, Gunter., Brodbeck, Felix., PM Celeste. Wilderom Cross-border transfer of knowledge: Cultural lessons from ProjectGLOBE., Academy of Management Executive, 2005, Vol. 19, No.2

xviii. Jeurissen, Ronald, (2004),Institutional Conditions of Corporate Citizenship, Journal of Business Ethics., Volume 53., Numbers 1-2., Pg.87-96

xix. [19] Jogiyanto, 2011, Structural Equation Modeling, Concept and Application Based on Variant in Business Research., UPP STIM YKPN, Yogyakarta.

xx. Kranz and Santalo, 2010, When Necessity Becomes A Virtue : The Effect of the Roduct Market Competition on Corporate Social Responsibility, Journal of Economics \& Management Strategy , Volume 19, Number 2, Summer 2010,453-487.

xxi. Meta-analysis. (2003). Organization Studies 24 (3): 403-441. SAGE Publications (London, Thousand Oaks, CA \& New Delhi).

xxii. Porter and Kramer (2006), The link between competitive advantage and corporate social responsibility, Harvard Business School Publishing Corporation, all rights reserved

xxiii. Skerlavaj et.al. (2007), Organizational Learning Culture-missing link between business process and organizational performance, International Journal of Production Economics, 106 p. 346-367.

]Slater, Stanley F., and John C. Narver. 1994. Does Competitive Environment Moderate the Market Orientation-Performance Relationship? Journal of Marketing,January, Volume 58. pp. 46-5514.

xxiv. Thoha, Miftah. 2010. Leadership in Management, PT. Raja Grafindo Persada, Jakarta.

xxv. Thomson, Higgins. 1991,'Personal Computing: Toward a Conceptual Model of Utilization', MIS Quarterly, March Edition.

xxvi. Triandis, HC (1995). Individualism and collectivism, Boulder, CO: Westview

xxvii. Verissimo and Lac Erda, (2011), The new age of corporate social and ethical consciousness: Toward a new leadership mindset, Proceedings of the 12 th Annual International Leadership Association ( www.ila-net.org ) Conference. Leadership 2.0: Time for Action, 27 Oct - 30 Oct., Boston, USA.

xxviii. Waldman, David A., Siegel, Donald S. and Javidan, M. (2006). Components of CEO Transformational Leadership and Corporate Social Responsibility,Journal of Management Studies, Dec. 2006, Vol. 43, No. 8,pp. 1703-1725.

xxix. Wheelen, L. Thomas and Hunger, J. David. 2001. Strategic Management. Addison-Wesley Publishing Company. Julianto Agung (translator). First Editing Strategic Managemen, Andi Yogyakarta publisher.

xxx. Yusuf, M., 2013, the Company Strategic Formulation on CSR Orientation and Its Implementation on Company Performance (A Study on the Industrial Area in Makassar), Dissertation, Doctoral Program of Management Science, Post Graduate Program, Faculty of Economics and Business, Brawijaya University. 